Jadila: Journal of Development and Innovation in Language and Literature Education

Publisher: Yayasan Karinosseff Muda Indonesia
E-ISSN: 2723-6900

P-ISSN: 2745-9578

Volume 1 Number 4, 2021

Page: 470-477

\title{
The Influence of Storytelling on EFL Students Motivation in Speaking Practice in SMPN 03 Bengkulu Tengah
}

\author{
Feny Martina \\ fenvmartina.ms@gmail. \\ comIAIN Bengkulu \\ Ali Akbarjono \\ aliakbari250975@gmail.com \\ IAIN Bengkulu \\ Sri Noprianti \\ noprianti98@gmail.com \\ IAIN Bengkulu
}

\begin{abstract}
Based on the explanation of the theory by Gardner the state is motivation comes from within a person as a driving force to achieve goals for more advanced change. This study aims to determine how enthusiastic for student's Eighth grade in the SMPN 03 Bengkulu Tengah are in learning English, especially speaking English. Researchers used a quasy-experimental research method, namely a control group posttest only design which showed in a significant difference between $74,92 \%$ and $61.96 \%$ of the experimental class in the control class. From this hypothesis, the researcher obtained a comparison of the experimental class in the treatment using the storytelling method of $4.34 \%$ and the control class with the narrative picture method of $3.58 \%$. So the researcher can conclude that there is a significant difference between the two methods with or without the use of treatment compared to the motivation to learn English in class VIII students at SMPN 03 Bengkulu Tengah.
\end{abstract}

Keywords: Storytelling, Motivation, speaking practice.

\section{A. Introduction}

Motivation is a person's motivation from within or from outside to achieve a certain goal (Nunan, 1983). Students motivation in learning is able to influence the entire learning and teaching process in the classroom, motivation is formed from within these students. In 2018, 
Jadila: Journal of Development and Innovation in Language and Literature Education

Publisher: Yayasan Karinosseff Muda Indonesia
E-ISSN: 2723-6900

P-ISSN: 2745-9578

Volume 1 Number 4, 2021

Page: 470-477

Nadiem Karim said that English was abolished at the junior high school (SMP) and senior high 
Jadila: Journal of Development and Innovation in Language and Literature Education Publisher: Yayasan Karinosseff Muda Indonesia
E-ISSN: 2723-6900

P-ISSN: 2745-9578

Volume 1 Number 4, 2021

Page: 470-477

school (SMA ) levels . Therefore, many teachers, especially teachers of English subjects, apply several new methods to be able to increase students 'enthusiasm in learning English especially in speaking because speaking is a skill which could be useful for students whether in academic or non-academic setting (syafryadin, 2020; Syafryadin, 2020). This study applies the storytelling method to train students' English in speaking English. According to Harmer (2007) \& Syafryadin, et al. (2019), storytelling is a method of teaching speaking skills so that students can briefly summarize a story or story they have heard from someone or media listeners before, or they can create their own stories to tell their classmates. This study aims to determine whether there is student motivation to learn English after notification of English subjects.

Then, researchers looked back at several previous studies such as Zuhriyah's (2017) study entitled ' Storytelling to Improve Students' Speaking Skills; The result showed that there was an improvement in students' speaking skills after the implementation of storytelling. The speaking test result in cycle two explained that the students' speaking aspects got good progress. Storytelling improved their comprehension, fluency, vocabulary, grammar, and pronunciation. Thus, it can be said that storytelling could improve students' speak ing skills with good motivation. There are also those who discuss student motivation in learning English such as research by Akhyak and Indramawan (2013: 18) in a study entitled "Improving students' English competence through storytelling ", storytelling that is applied in teaching speaking can improve student fluency, grammar, pronunciation, vocabulary, and content contained in the content of the story the fable.

In this study, researchers received research questions in the form of ; is there any influence of storytelling to increase the motivation of students to practice speaking the language of English. Answer questions research is answered in chapter discussion that there

are two possibilities, is there an influence of storytelling on the motivation of the students in learning the language, but otherwise did not exist the influence of methods.

\section{B. Research Method}

The researcher used the storytelling method to collect data. The research design was quasi-experimental research used Sugiono modification design. One of them in the form of an experimental design used by researchers was the Control Group Posttest Only Design . In this design, either the experimental group or control group was given without in experiment group (Sugiono, 2015; Creswell, 2014; Ary, et al. 2010), speaking in structure to be employed by the teacher was through the implementation of storytelling technique. The researcher conducted the research by Choosing the right place is important in a study; therefore it was able to influence the results of research with a period of 6 meetings a month. So, the researcher chose SMP Negeri 03 center of Bengkulu as the background for the study. It was located on Kembang Seri Street, 
Jadila: Journal of Development and Innovation in Language and Literature Education

Publisher: Yayasan Karinosseff Muda Indonesia
E-ISSN: 2723-6900

P-ISSN: 2745-9578

Volume 1 Number 4, 2021

Page: 470-477

Bengkulu - Curup, Center of Bengkulu. Meanwhile, the sample in this study consisted of 2 classes VIII, namely the control class in class VIII A and the experimental class in class VIII B with 26 students in both of them.

To obtain valid data, the researcher used three instruments namely;

a) The speaking test

The researcher gave an oral test at the treatment session. The treatment used by researcher is to provide treatment in the form of knowledge and also choose what fairy tales were retold using appropriate media.

b) Questionnaire

The researcher was provided questionnaires to students to measure students' initial motivation and research what are the motivational points. In this study, the researcher conducted a division of questionnaires as one of the data collection techniques.

c) Interviews

Researchers conduct interviews of the two positions namely from the opinion of the students and also the opinion of data addition to research this, because taking the teachers. Interview intended as a data directly in private about the motivation of students to learn the language of English that uses methods storytelling.

The researcher used several steps of data analysis collected from document analysis and interviews. It was a drawing of conclusions / verification: conclusions were supplemented using supporting evidence and the results of data collection.

In this study, researchers used an online system due to the Covid 19 pandemic that is currently sweeping around the world, researchers used zoom meetings and WhatSapp chat as an alternative to carry out treatment and also provide questionnaires to students . In a study this, researchers use the something like record, photos, and also a document from the school.

\section{Results and Discussion}

Based on the results of the research conducted and analyzing the results of the pretest and posttest. The posttest is given to students in the Eighth Grade (8B) as the treatment class using storytelling with a total of 26 students and (8A) as a control class using picture narrating with a total of 26 students. The first instrument was given to students before the researchers conducted the study with metacognitive strategies and the posttest was given to students at the end of the study after using the method.

The questionnaire sheets data were obtained using the online Google form and the results of the treatment using the storytelling method were done via online video call WhatsApp 
Jadila: Journal of Development and Innovation in Language and Literature Education Publisher: Yayasan Karinosseff Muda Indonesia
E-ISSN: 2723-6900

P-ISSN: 2745-9578

Volume 1 Number 4, 2021

Page: 470-477

and zoom meeting online, then the data results were published in the form of documentation in the form of a screenshot treatment using the storytelling method and voice notes from students. Based on field notes, namely from the results of interviews conducted by researchers with English teachers at SMPN 03 Bengkulu Tengah (DV) said that in dealing with lazy students, there needs to be a lot of evaluation in terms of teaching methods, methods and motivating students when learning to speak English. On the other side, the school has met the standards of media (audio, books, and projectors).

From the results of the above data, the researcher found a comparison between the experimental class and the control class in answering the speaking test distributed by the researcher. The data is described in the T-test analysis table below:

Table 1. Analysis of the T test of student's motivation

\begin{tabular}{|c|c|c|}
\hline \multicolumn{3}{|c|}{ t-Test: Paired Two Sample for Means } \\
\hline & & ample \\
\hline & $\begin{array}{c}\text { Class } B \\
\text { (treatment class) }\end{array}$ & $\begin{array}{r}\text { Class A } \\
\text { (control class) }\end{array}$ \\
\hline Mean & 75,03846 & 61.96154 \\
\hline Variance & 73,07846 & 47,31846 \\
\hline $\begin{array}{l}\text { Observation } \\
\mathrm{s}\end{array}$ & 26 & 26 \\
\hline $\begin{array}{l}\text { Pearson } \\
\text { Correlation }\end{array}$ & -0.03538 & \\
\hline $\begin{array}{l}\text { Hypothesize } \\
\text { d Mean Difference }\end{array}$ & 0 & \\
\hline Df & 25 & \\
\hline t Stat & 5,974667 & \\
\hline $\begin{array}{l}\text { P }(\mathrm{T}<=\mathrm{t}) \\
\text { one-tail }\end{array}$ & $1.54 \mathrm{E}-06$ & \\
\hline $\begin{array}{l}\text { t Critical } \\
\text { one-tail }\end{array}$ & 1,708141 & \\
\hline $\begin{array}{l}\text { P }(\mathrm{T}<=\mathrm{t}) \\
\text { two-tail }\end{array}$ & $3,08 \mathrm{E}-06$ & \\
\hline $\begin{array}{l}\text { t Critical } \\
\text { two-tail }\end{array}$ & 2.059539 & \\
\hline
\end{tabular}

The average or mean the difference between classes B and A after doing the speaking test in the table above is between 75 and 61 , so there is a difference between the treatment and not giving the treatment. The variant results also experienced differences, namely 73 and 47 with a 
Jadila: Journal of Development and Innovation in Language and Literature Education Publisher: Yayasan Karinosseff Muda Indonesia
E-ISSN: 2723-6900

P-ISSN: 2745-9578

Volume 1 Number 4, 2021

Page: 470-477

sample of 26 students and $d f 26-1$ is 25 . Then the $t$ state description of 5.97 is obtained which is the same as the difference between the two. The hypothesis using two tails with the result of $\mathrm{t}$ table is 2.0590539 with ap value of $3.08 \mathrm{E}-06$. Therefore, the $\mathrm{p}$ value is smaller than alpha 5\%, the result is accepted H1. Hypothesis H1 concluded that there is a significant difference between treatment and not given treatment. The researcher also analyzed the results received when doing the speaking test based on the procedure. It is described in the table below:

Table 1. Result of Treatment Class and Control class

\begin{tabular}{|c|c|c|c|}
\hline o. & Criteria & Treatment class & Control class \\
\hline. & Fluency & 4.44 & 3.07 \\
\hline. & $\begin{array}{c}\text { Pronunciati } \\
\text { on }\end{array}$ & 4.47 & 4.37 \\
\hline & Accuracy & 4.14 & 3.09 \\
\hline$\cdot$ & Clarity & 4.39 & 4.10 \\
\hline. & $\begin{array}{c}\text { Performanc } \\
\text { e skills }\end{array}$ & 4.30 & 3.29 \\
\hline & Total & $\mathbf{4 . 3 4}$ & $\mathbf{3 . 5 8}$ \\
\hline
\end{tabular}

From the table above, it can be seen that the effect of treatment and not being given treatment is between 4.34 to $3,58 \%$. The difference is about $76 \%$ per aspect. The overall results of the data above, the researcher concluded that the students' motivation in learning English in the classroom, especially when speaking test in class B, got had a high degree of motivation and class A got had a moderate degree of motivation with scala likert explanation.

After the explanation above, the researcher also analyzed data from the motivation questionnaire given to students totaling 20 questions, which were analyzed using the unit analysis method, the activities given at the end of the treatment. It is described in the table below :

Table 1. Analysis unit questionnaire test of student's motivation

\begin{tabular}{|c|c|c|c|}
\hline \multicolumn{4}{|c|}{ Statistics } \\
\hline & & & Co \\
\hline & & $\begin{array}{c}\text { eriment } \\
\text { class }\end{array}$ & ntrol class \\
\hline \multirow[t]{3}{*}{$\mathrm{N}$} & $\mathrm{V}$ & 26 & 26 \\
\hline & alid & & \\
\hline & $\mathrm{M}$ & 2 & 2 \\
\hline
\end{tabular}


Jadila: Journal of Development and Innovation

E-ISSN: 2723-6900

in Language and Literature Education

P-ISSN: 2745-9578

Publisher: Yayasan Karinosseff Muda Indonesia

Volume 1 Number 4, 2021

Page: $470-477$

\begin{tabular}{|c|c|c|}
\hline issing & & \\
\hline Mean & $\begin{array}{r}74 . \\
92\end{array}$ & $\begin{array}{c}61 . \\
96\end{array}$ \\
\hline $\begin{array}{ll}\text { Std. Error of } \\
\text { Mean }\end{array}$ & $\begin{array}{r}1,3 \\
78\end{array}$ & $\begin{array}{r}1,6 \\
79\end{array}$ \\
\hline Median & $\begin{array}{r}75 . \\
50\end{array}$ & $\begin{array}{r}60 . \\
00\end{array}$ \\
\hline Mode & 80 & 60 \\
\hline $\begin{array}{l}\text { Std. Deviati } \\
\text { on }\end{array}$ & $\begin{array}{r}7,0 \\
25\end{array}$ & $\begin{array}{r}8,5 \\
63\end{array}$ \\
\hline Kurtosis & $\begin{array}{r}-- \\
368\end{array}$ & $\begin{array}{r}-, \\
265\end{array}$ \\
\hline $\begin{array}{l}\text { Std. Error of } \\
\text { Kurtosis }\end{array}$ & 887 & 887 \\
\hline Range & 27 & 35 \\
\hline Minimum & 61 & 45 \\
\hline Maximum & 88 & 80 \\
\hline Sum & $\begin{array}{r}194 \\
8\end{array}$ & $\begin{array}{l}16 \\
11\end{array}$ \\
\hline
\end{tabular}

The overall results of the data from the experimental class which had a percentage of 75 , $50 \%$ and while the control class had a percentage of $60,00 \%$ showed that students had high motivation towards learning English in class, especially in the field of questionnaires, but this comparison was different from the results class A and B about choosing answers about their motivation in learning English.

Then, based on the results of the hypothesis with the 1-way ANOVA test conducted by the researcher using the SPSS version 25 program, the significance value of $0.000<\alpha=0.05$ was obtained, so $\mathrm{H} 0$ was rejected, which means that there was an influence between the learning method on the motivation to learn English of class VIII students at SMPN 03 Central Bengkulu. So it can be said that the difference between the method and also the provision of treatment in the teaching and learning process is very important, because sometimes teachers in class face students who are lazy, bored, bored, and so on. so that this situation cannot be ignored because this can reduce student motivation when the teaching and learning process takes place.

\section{Conclusion}

Based on the explanation above, there is no significant influence between the pictures narrating method or without prior simulation on the learning motivation of class VIII A students in English subjects at SMPN 03 Bengkulu in the middle of the 2020/2021 academic year. H1 = 
Jadila: Journal of Development and Innovation in Language and Literature Education Publisher: Yayasan Karinosseff Muda Indonesia
E-ISSN: 2723-6900

P-ISSN: 2745-9578

Volume 1 Number 4, 2021

Page: 470-477

there is at least one $r \mathrm{i} \neq 1$, which means that the method without treatment only affects $1 \%$ of student learning motivation. Meanwhile, There is an influence on the storytelling method by providing treatment on the motivation to learn English of class VIII B students in English subjects at SMPN 03 Bengkulu in the middle of the 2020/2021 academic year. This is indicated by the results of the data hypothesis test with a value of $\mathrm{P}=0.000<0.05$, then $\mathrm{H} 0$ is rejected.

After the research done, the researcher want to give some advice for the next researcher are $t$ eachers should use appropriate learning methods, and it would be better if they use media aids in the learning process so that children become more motivated in learning, For students, it can foster enthusiasm for learning because the use of media tends not to be boring so that students are motivated to continue learning, and For students, learning English can compete in world education.

\section{References}

Ary, D., Jacobs, L. C., \& Sorensen, C. (2010). Introduction to Research in. Education. USA: Wadsworth.

Creswell, J. W. (2014). Research Design: Qualitative, Quantitative and Mixed Methods. Approaches: Fourth edition. Thousand Oaks, CA: Sage Publications.

Harmer, J. (2007). How to teach English , (China: Pearson Education Limited, 2007), p. 89

Observation of Student's motivation in speaking skills of Eight Grade at SMPN 03 Bengkulu Tengah on March 09, 2020, at 08.00 am.

Nunan, D. Language Teaching Methodology. (Sydney: Prentice-Hall International, 1983). p. 223 Sugiono. (2015). Quantitative Research Methods, Qualitative and R \& D. (Bandung: CV. Alfabeta, 2015) p. 112

Syafryadin, H., \& Salniwati, A. R. A. P. (2019). Digital Storytelling Implementation for Enhancing Students' Speaking Ability in Various Text Genres. International Journal of Recent Technology and Engineering (IJRTE). 8(4), 3147-3151.

Syafryadin, S. (2020). The Effect of Talking Chips Technique Toward the Improvement of Students' Speaking Achievement at one of the Senior High Schools in Bandung. Linguists: Journal Of Linguistics and Language Teaching, 6(2), 1-13. 
Jadila: Journal of Development and Innovation in Language and Literature Education

Publisher: Yayasan Karinosseff Muda Indonesia
E-ISSN: 2723-6900

P-ISSN: 2745-9578

Volume 1 Number 4, 2021

Page: 470-477

Syafryadin, S. (2020). Students' Strategies in Learning Speaking: Experience of Two Indonesian Schools. Vision: Journal for Language and Foreign Language Learning, 9(1), 33-46.

_D V , English teacher of SMPN 03 Bengkulu Tengah, at March 09, 2020. 